\title{
GLP-1 Receptor Agonists in Type 2 Diabetes and Beyond - New Insights 2015
}

\author{
Baptist Gallwitz \\ Deputy Chief, Department of Medicine IV; Head of the Outpatient Clinic for Diabetes and Endocrinology, Eberhard Karls University, Germany
}

\begin{abstract}
Glucagon-like peptide-1 receptor agonists (GLP-1 RAS) were introduced for type 2 diabetes therapy nearly 10 years ago, among them short-acting compounds on the basis of the GLP-1-like peptide exendin-4 (exenatide and lixisenatide) and a long-acting GLP-1 RA based on the human GLP-1 sequence (liraglutide). Recently, two novel long-acting GLP-1 RAs on the basis of human GLP-1 sequence, for onceweekly application, have been approved for therapy of type 2 diabetes. Additionally, liraglutide has been approved for treatment of obesity at a higher dose than that used for diabetes therapy. This mini-review gives a short overview of the novel long-acting GLP-1 RAS albiglutide and dulaglutide and also reviews the studies of liraglutide in treatment of obesity leading to its approval for this use. These studies were largely presented at the annual meeting of the European Association for the Study of Diabetes (EASD) in fall 2014.
\end{abstract}

\section{Keywords}

Type 2 diabetes, obesity, GLP-1 receptor agonists, albiglutide, dulaglutide, liraglutide

Disclosure: Baptist Gallwitz has attended advisory boards for AstraZeneca, Boehringer Ingelheim, Bristol-Myers Squibb, Eli Lilly \& Co, Janssen, Novartis, Novo Nordisk, Roche and Merck \& Co; has received research support from AstraZeneca, Boehringer Ingelheim, Eli Lilly \& Co, Novartis and Novo Nordisk and has attended speaker's bureaux for AstraZeneca, Berlin Chemie AG, Bristol-Myers Squibb, Boehringer Ingelheim, Eli Lilly \& Co, Merck \& Co, Novartis, Novo Nordisk, Roche, Sanofi and Takeda. No funding was received for the publication of this article.

Open Access: This article is published under the Creative Commons Attribution Noncommercial License, which permits any noncommercial use, distribution, adaptation and reproduction provided the original author(s) and source are given appropriate credit.

Received: 26 February 2015 Accepted: 17 March 2015 Citation: European Endocrinology, 2015;11(1):21-5 DOl:10.17925/EE.2015.11.01.21

Correspondence: Baptist Gallwitz, Dept. Medicine IV, Eberhard Karls University, Otfried-Müller-Str. 10, 72076 Tübingen, Germany. E: baptist.gallwitz@med.uni-tuebingen.de

Glucagon-like peptide-1 receptor agonists (GLP-1 RAS) were introduced for the therapy of type 2 diabetes about 10 years ago, with exenatide the first drug in the class. Natural GLP-1 is secreted post-prandially by the L-cells of the intestine. It stimulates insulin secretion and inhibits glucagon secretion in a glucose-dependent manner. In addition to having direct effects on glucose metabolism, GLP-1 also slows gastric emptying, acts as a neurotransmitter in hypothalamic nuclei stimulating satiety, lowers blood pressure and has a positive influence on beta cell mass in animal models with high beta cell turn-over. Because GLP-1 itself has a very short half-life, long-acting GLP-1 RAs have been designed to use GLP-1 action for type 2 diabetes therapy. ${ }^{1,2}$

Recently, two GLP-1 RAs for once-weekly injection were approved for the treatment of type 2 diabetes. Albiglutide (Eperzan ${ }^{\circledR}$, GlaxoSmithKline Pharmaceuticals) and dulaglutide (Trulicity ${ }^{\circledR}$, Lilly Pharmaceuticals) are based on the human GLP-1 peptide sequence, whereas exenatide for onceweekly use (Bydureon ${ }^{\circledR}$, AstraZeneca Pharmaceuticals), introduced in 2012, is based on the sequence of exendin-4, a peptide with $>50 \%$ sequence homology to human GLP-1.-5 Apart from this difference, exenatide for once-weekly use has a long pharmacological action thanks to galenic preparation, with a retarded and slow continuous release of exenatide from a suspension of soluble microspheres loaded with the compound. ${ }^{6}$

This review aims to give an overview of the recently published clinical study data on the novel long-acting GLP-1 RAs albiglutide and dulaglutide with a human GLP-1 ligand. In addition, recent data on the long-acting
GLP-1 receptor agonist liraglutide, which also has a human GLP-1 sequence and is for treating obesity, are presented. Most of the clinical study data dealt with in this article were presented at the recent annual meeting of the European Association for the Study of Diabetes (EASD) 2014. These data were also prerequisites for the approval of albiglutide and dulaglutide for the treatment of type 2 diabetes with once-weekly injections. The indication for liraglutide was widened to additionally include the treatment of morbid obesity without type 2 diabetes.

\section{Albiglutide}

Albiglutide is a molecule consisting of two copies of a 30-amino acid sequence of a human GLP-1 dimer genetically fused to human albumin. Degradation is inhibited by a single amino acid substitution within the GLP-1 fragment. Additionally, the fusion to albumin results in a longer halflife. Maximum concentrations of albiglutide are reached 3 to 5 days after a subcutaneous dose, and steady-state concentrations are achieved after 4 to 5 weeks of once-weekly administration.?

Albiglutide has been studied in a set of prospective randomized clinical studies at various stages of type 2 diabetes and in different combination therapies. An overview of the comparative clinical study programme with albiglutide is given in Table 1. In summary, the programme consisted of eight independent studies (HARMONY 1 to HARMONY 8) with the usual primary endpoint of glycated haemoglobin $\left(\mathrm{HbA}_{1 \mathrm{c}}\right)$ reduction at 26,32 , 52 or 104 weeks. Overall, the trials involved more than 5,000 patients, including more than 2,000 patients on albiglutide, representing more than 
Table 1: Glycaemic Efficacy and Body Weight Changes in the Phase III Clinical Studies with Albiglutide (HARMONY Studies; summarised from references 8-16)

\begin{tabular}{|c|c|c|c|c|c|c|c|}
\hline Study (Reference) & $\begin{array}{l}\text { Comparator and Treatment Arms } \\
\text { (Number of Patients) }\end{array}$ & $\begin{array}{l}\text { Duration } \\
\text { (Weeks) }\end{array}$ & $\begin{array}{l}\text { Baseline } \\
\mathrm{HbA}_{1 \mathrm{c}}(\%)\end{array}$ & $\begin{array}{l}\text { Change in } \\
\mathrm{HbA}_{1 \mathrm{c}}(\%)\end{array}$ & $\begin{array}{l}\text { Baseline } \\
\text { Body } \\
\text { Weight (kg) }\end{array}$ & $\begin{array}{l}\text { Change } \\
\text { in Body } \\
\text { Weight (kg) }\end{array}$ & $\begin{array}{l}\text { Patients } \\
\text { Needing } \\
\text { Rescue } \\
\text { Therapy (\%) }\end{array}$ \\
\hline HARMONY 1 & $\mathrm{ALB}+\mathrm{PIO} \pm \mathrm{MET}(149)$ & 52 & 8.1 & $-0.81^{*}$ & 98 & 0.3 & $24.4^{*}$ \\
\hline Reusch et al. $2014^{9}$ & $\begin{array}{l}\mathrm{PBO}+\mathrm{PIO} \pm \mathrm{MET}(150) \\
\text { ALB dose } 30 \mathrm{mg} \\
\text { MET dose } \geq 1,500 \mathrm{mg} \\
\text { PIO dose } \geq 30 \mathrm{mg}\end{array}$ & & 8.1 & -0.05 & 100 & 0.5 & 47.7 \\
\hline HARMONY 2 & ALB 30 mg (100) & 52 & 8.1 & -0.7 * & - & -0.7 & 20 \\
\hline Nauck et al. $2013^{10}$ & $\begin{array}{l}\text { ALB } 50 \text { mg (97) } \\
\text { PBO (99) }\end{array}$ & & $\begin{array}{l}8.2 \\
8.0\end{array}$ & $\begin{array}{l}-0.89 * \\
0.15\end{array}$ & $\begin{array}{l}- \\
-\end{array}$ & $\begin{array}{l}-0.9 \\
-0.7\end{array}$ & $\begin{array}{l}16 \\
50\end{array}$ \\
\hline $\begin{array}{l}\text { HARMONY } 3 \\
\text { Ahren et al. } 2014^{11}\end{array}$ & $\begin{array}{l}\text { ALB+MET (297) } \\
\text { SIT+MET (300) } \\
\text { GLM+MET (302) } \\
\text { PBO+MET (100) } \\
\text { MET dose } \geq 1,500 \mathrm{mg} \\
\text { SIT dose } 100 \mathrm{mg} \\
\text { GLM dose 2-4 mg (mean } 3.1 \mathrm{mg} \text { ) } \\
\text { ALB dose } 30-50 \text { mg (mean } 40.5 \text { mg) }\end{array}$ & 104 & $\begin{array}{l}8.1 \\
8.1 \\
8.1 \\
8.1\end{array}$ & $\begin{array}{l}-0.63^{\star \wedge} \\
-0.28 \\
-0.36 \\
0.27\end{array}$ & $\begin{array}{l}90 \\
90 \\
92 \\
92\end{array}$ & $\begin{array}{l}-1.2^{\star *} \\
-0.9 \\
1.2 \\
-1.0\end{array}$ & $\begin{array}{l}25.8^{* \|} \\
36.4 \\
32.7 \\
59.2\end{array}$ \\
\hline $\begin{array}{l}\text { HARMONY } 4 \\
\text { Weissmann et al. } 2014^{12}\end{array}$ & $\begin{array}{l}\text { ALB+MET } \pm \text { SU (496) } \\
\text { GLA+MET } \pm S U \text { (239) } \\
\text { MET dose } \geq 1,500 \text { mg ( } 82 \% \text { on MET+SU) } \\
\text { ALB dose } 30-50 \text { mg ( } 67 \% \text { on } 50 \text { mg) } \\
\text { GLA dose titrated per protocol (mean } 35 \mathrm{U} \text { ) }\end{array}$ & 52 & $\begin{array}{l}8.3 \\
8.4\end{array}$ & $\begin{array}{l}-0.67^{\S} \\
-0.79\end{array}$ & $\begin{array}{l}95 \\
95\end{array}$ & $\begin{array}{l}-1.1^{\wedge} \\
1.6\end{array}$ & $\begin{array}{l}25.6 \\
23.8\end{array}$ \\
\hline $\begin{array}{l}\text { HARMONY } 5 \\
\text { Home et al. } 2014^{13}\end{array}$ & $\begin{array}{l}\text { ALB+MET+GLM (269) } \\
\text { PIO+MET+GLM (273) } \\
\text { PBO+MET+GLM (115) } \\
\text { MET dose } \geq 1,500 \text { mg } \\
\text { GLM dose } 4 \text { mg } \\
\text { ALB dose } 30-50 \text { mg } \\
\text { (70.1 \% on } 50 \text { mg) } \\
\text { PIO dose } 30-45 \text { mg (54.9\% on } 45 \text { mg) }\end{array}$ & 52 & $\begin{array}{l}8.2 \\
8.3 \\
8.3\end{array}$ & $\begin{array}{l}-0.55^{\star \|} \\
-0.80 \\
0.33\end{array}$ & $\begin{array}{l}91 \\
91 \\
90\end{array}$ & $\begin{array}{l}-0.4^{* *} \\
4.4 \\
-0.4\end{array}$ & $\mathrm{n} / \mathrm{a}$ \\
\hline $\begin{array}{l}\text { HARMONY } 6 \\
\text { Rosenstock et al. } 2014^{14}\end{array}$ & $\begin{array}{l}\text { ALB+GLA } \pm \text { OAD (282) } \\
\text { Lispro+GLA } \pm \text { OAD (281) } \\
\text { Baseline OADs allowed: PIO, MET, AGI } \\
68 \% \text { MET only; } 6 \% \text { MET+PIO; } 23 \% \text { neither } \\
\text { GLA titrated per protocol (mean } 53.2 \mathrm{cU} \text { ) } \\
\text { ALB 30-50 mg ( } 51 \% \text { on } 50 \text { mg) } \\
\text { Lispro adjusted per protocol (mean } 50.6 \mathrm{cU} \text { ) }\end{array}$ & 26 & $\begin{array}{l}8.5 \\
8.4\end{array}$ & $\begin{array}{l}-0.82^{\S} \\
-0.66\end{array}$ & $\begin{array}{l}93 \\
92\end{array}$ & $\begin{array}{l}-0.7^{\wedge} \\
0.8\end{array}$ & $\begin{array}{l}22.9 \\
24.4\end{array}$ \\
\hline $\begin{array}{l}\text { HARMONY } 7 \\
\text { Pratley et al. } 2014^{15}\end{array}$ & $\begin{array}{l}\text { ALB }+\geq 1 \text { OAD (402) } \\
\text { Lira }+\geq 1 \text { OAD (403) } \\
\text { Baseline OADs allowed: MET, TZD, SU } \\
\sim 40 \% \text { monotherapy, } 50 \% \text { two drugs } \\
\text { ALB titrated to } 50 \mathrm{mg} \\
\text { Lira titrated to } 1.8 \mathrm{mg}\end{array}$ & 32 & $\begin{array}{l}8.2 \\
8.2\end{array}$ & $\begin{array}{l}-0.78^{\$} \\
-0.99\end{array}$ & $\begin{array}{l}92 \\
93\end{array}$ & $\begin{array}{l}-0.6 \\
-2.2^{n}\end{array}$ & $\begin{array}{l}15 \\
8\end{array}$ \\
\hline HARMONY 8 & $\mathrm{ALB} \pm \mathrm{OAD}(246)$ & 26 & 8.1 & $-0.83^{\wedge}$ & 83.3 & $-0.79^{\wedge}$ & $6.1^{\wedge}$ \\
\hline Leiter et al. $2014^{16}$ & $\begin{array}{l}\mathrm{SIT} \pm \mathrm{OAD}(240) \\
\text { ALB 30-50 mg (mean } 42.4 \text { mg) }\end{array}$ & & 8.2 & -0.52 & 82.8 & -0.19 & 12.1 \\
\hline
\end{tabular}

$A G I=$ alpha-glucosidase inhibitors; $A L B=$ albiglutide; $G L A=$ insulin glargine; $G L M=$ glimepiride; Lira = liraglutide; $M E T=$ metformin; $O A D=$ oral anti-diabetic agent; $P B O=$ placebo $P I O=$ pioglitazone; SIT = sitagliptin; *ALB significant versus $P B O ; \wedge A L B$ significant versus active comparator; **ALB significant versus GLM; $\| A L B$ significant versus SIT; ${ }^{s} A L B$ noninferior to active comparator, "Non-inferiority of $A L B$ versus active comparator not met; "Comparator significant versuS ALB.

7,500 patient-years of treatment. The mean baseline $\mathrm{HbA}_{1 \mathrm{c}}$ for the study population ranged from $8.0 \%$ to $8.5 \%$, and the mean baseline body weight was 83-95 kg.8-16

An $\mathrm{HbA}_{1 \mathrm{c}}$ reduction of $-0.55 \%$ to $-0.9 \%$ was observed in these studies, and albiglutide was found superior to treatment using a sulphonylurea, pioglitazone or dipeptidyl peptidase-4 (DPP4) inhibitor. Non-inferiority was demonstrated versus insulin therapy. ${ }^{3}$ The mean body weight change was lower in comparison to other GLP-1 RAs, amounting to 0.3 to $-1.2 \mathrm{~kg}$, and was less when albiglutide was combined with oral anti-diabetics known to cause weight gain (pioglitazone, sulphonylurea). ${ }^{8-16}$

The overall hypoglycaemia rates were low, similar to those of other GLP1 RAs, when albiglutide was used as monotherapy or in combination 
Table 2: Glycaemic Efficacy and Body Weight Changes in the Phase III Clinical Studies with Dulaglutide (AWARD Studies; summarized from references 18-24)

\begin{tabular}{|c|c|c|c|c|c|c|}
\hline Study (Reference) & $\begin{array}{l}\text { Comparator and Treatment Arms } \\
\text { (Number of Patients) }\end{array}$ & $\begin{array}{l}\text { Duration } \\
\text { (weeks) }\end{array}$ & $\begin{array}{l}\text { Baseline } \\
\mathrm{HbA}_{1 \mathrm{c}}(\%)\end{array}$ & $\begin{array}{l}\text { Change in } \\
\mathrm{HbA}_{1 \mathrm{c}}(\%)\end{array}$ & $\begin{array}{l}\text { Baseline Body } \\
\text { Weight (kg) }\end{array}$ & $\begin{array}{l}\text { Change in Body } \\
\text { Weight }(\mathrm{kg})\end{array}$ \\
\hline AWARD 1 & DU 0.75+PIO+MET (263) & 26 & 8.1 & $-1.30^{\wedge} \star$ & 96 & 0.2 \\
\hline \multirow[t]{5}{*}{ Wysham et al. $2014^{18}$} & DU 1.5+PIO+MET (260) & & 8.1 & $-1.51^{\wedge \star}$ & 96 & -1.3 \\
\hline & EXE 10+PIO+MET (252) & & 8.1 & $-0.99 *$ & 97 & -1.07 \\
\hline & $\mathrm{PBO}+\mathrm{PIO}+\mathrm{MET}(124)$ & & 8.1 & -0.46 & 94 & 1.24 \\
\hline & MET dose $\geq 1,500 \mathrm{mg}$ & & & & & \\
\hline & $\mathrm{PIO}$ dose $\geq 30 \mathrm{mg}$ & & & & & \\
\hline AWARD 2 & DU 0.75 mg (272) & 52 & 8.1 & $-0.76^{\S}$ & 86.3 & $-1.33^{\S}$ \\
\hline \multirow[t]{4}{*}{ Giorgino et al. $2014^{19}$} & DU 1.50 mg (273) & & (average for all & $-1.08^{\wedge}$ & (average for all & $-1.87^{\S}$ \\
\hline & GLA (262) & & groups) & -0.63 & groups) & 1.44 \\
\hline & MET dose $\geq 1,500 \mathrm{mg}$ & & & & & \\
\hline & Average GLA dose $29.4 \mathrm{U}$ & & & & & \\
\hline AWARD 3 & DU 0.75 mg (242) & 26 & 7.6 & $-0.71^{\wedge}$ & 93 & -1.36 \\
\hline \multirow[t]{3}{*}{ Umpierrez et al. $2014^{20}$} & DU 1.50 mg (233) & & 7.6 & $-0.78^{\wedge}$ & 92 & -2.29 \\
\hline & GLA (226) & & 7.6 & -0.56 & 92 & -2.22 \\
\hline & MET dose $\geq 1,500 \mathrm{mg}$ & & & & & \\
\hline AWARD 4 & DU 0.75 mg (293) & 26 & 8.5 & $-1.59^{\wedge}$ & 91.1 & $0.18^{* \star}$ \\
\hline \multirow[t]{9}{*}{ Jendle et al. $2014^{21}$} & DU 1.50 mg (295) & & (average for all & $-1.64^{\wedge}$ & (average for all & $-0.87 * *$ \\
\hline & GLA (296) & & groups) & -1.41 & groups) & 2.33 \\
\hline & MET dose $\geq 1,500 \mathrm{mg}$ & & & & & \\
\hline & GLA dose titrated per protocol & & & & & \\
\hline & (mean $65 \mathrm{U}$ ) & & & & & \\
\hline & Lispro dose at endpoint: & & & & & \\
\hline & 97 U for DU $0.75 \mathrm{mg}$ & & & & & \\
\hline & 93 U for DU 1.5 mg & & & & & \\
\hline & $68 \mathrm{U}$ for GLA & & & & & \\
\hline AWARD 5 & DU 0.75+MET (268) & 52 & 8.2 & $-0.87^{\wedge}$ & 86 & $-2.60^{\wedge *}$ \\
\hline \multirow[t]{4}{*}{ Nauck et al. $2014^{22,23}$} & DU 1.5+MET (258) & & 8.1 & $-1.10^{\wedge}$ & 87 & $-3.03^{\wedge *}$ \\
\hline & SITA 100+MET (270) & & 8.1 & -0.39 & 86 & -1.53 \\
\hline & $\mathrm{PBO}+\mathrm{MET}(124)$ & & 8.1 & & 87 & \\
\hline & MET dose $\geq 1,500$ mg & & & & & \\
\hline AWARD 6 & DU 1.5 mg+MET (269) & 26 & 8.1 & $-1.42^{\wedge}$ & 93.8 & -2.90 \\
\hline \multirow[t]{2}{*}{ Dungan et al. $2014^{24}$} & Lira 1.8 mg+MET (269) & & 8.1 & -1.36 & 94.4 & $-3.61^{\wedge}$ \\
\hline & MET dose $\geq 2,000$ mg & & & & & \\
\hline
\end{tabular}

$D U=$ dulaglutide; $G L A=$ insulin glargine; Lira = liraglutide; $M E T=$ metformin; $P B O=$ placebo; $P I O=$ pioglitazone; SIT = sitagliptin; * $D U$ significant versus PBO; $D D U$ superior versus active comparator; ${ }^{*} D U$ significant versus GLA; ${ }^{5} D U$ noninferior to active comparator.

with metformin or pioglitazone. Higher rates were observed only in combination with a sulphonylurea or insulin. As expected when using a GLP-1 RA, the most commonly reported adverse events were gastrointestinal and occurred at a higher rate than with placebo, pioglitazone, sulphonylurea, a DPP-4 inhibitor or insulin, but less frequently than with liraglutide. ${ }^{8-16}$

The advantages of albiglutide include once-weekly dosing and fewer gastrointestinal side effects than the GLP-1 RA liraglutide, but it is less effective at reducing $\mathrm{HbA}_{1 \mathrm{c}}$ and body weight than liraglutide is. On the other hand, it is effective, safe and approved for patients who have renal impairment. ${ }^{16,17}$

\section{Dulaglutide}

Dulaglutide has two human GLP-1 analogues fused to an immunoglobulin (Ig)-G fragment via two short peptide linkers. The half-life after injection amounts to $\sim 90$ hours. It is a clear solution, injected with a pen device. In clinical trials, $\mathrm{HbA}_{1 \mathrm{c}}$ reductions and weight loss typical for a GLP1 RA were observed. Dulaglutide was tested in clinical phase II and III studies in the AWARD study programme. These trials had a similar design, testing two doses of dulaglutide $(0.75 \mathrm{mg}$ and $1.5 \mathrm{mg}$ once weekly versus placebo or active comparator for 26-104 weeks). In total, the study population included in this programme comprised more than 5,000 patients, among them more than 3,000 patients on dulaglutide in monotherapy, dual therapy and complex treatment regimes, including insulin. ${ }^{17-24}$ The results from the AWARD studies 1-6 are published. ${ }^{17-24}$ The mean baseline $\mathrm{HbA}_{1 \mathrm{c}}$ for the study population ranged from $7.6 \%$ to $8.5 \%$ and the mean baseline body weight from $86 \mathrm{~kg}$ to $96 \mathrm{~kg} \cdot{ }^{17-24} \mathrm{An}$ overview of the comparative clinical study programme with dulaglutide is given in Table 2 .

The AWARD studies 7-9 are still ongoing, with results expected soon (AWARD 7: a study in patients with renal insufficiency dulaglutide vs. insulin glargine with insulin lispro in both study arms [ClinicalTrials.gov identifier: NCT01621178], AWARD 8: dulaglutide vs. placebo as add on to sulfonylurea [ClinicalTrials.gov identifier: NCT01769378], AWARD 9: dulaglutide vs. placebo as add on to metformin and insulin glargine [ClinicalTrials.gov identifier: NCT02152371]). In a direct comparison, the add -on of dulaglutide to patients failing on metformin was non-inferior compared with the addition of insulin glargine at the $0.75 \mathrm{mg}$ dose and superior at the $1.5 \mathrm{mg}$ dose. ${ }^{4} \mathrm{~A}$ direct head-to-head study comparing liraglutide with dulaglutide (in their respective maximal doses approved for type 2 diabetes therapy) showed non-inferiority for dulaglutide regarding the reduction of $\mathrm{HbA}_{1 \mathrm{c}}$ and body weight. ${ }^{17,24}$ The incidence of 


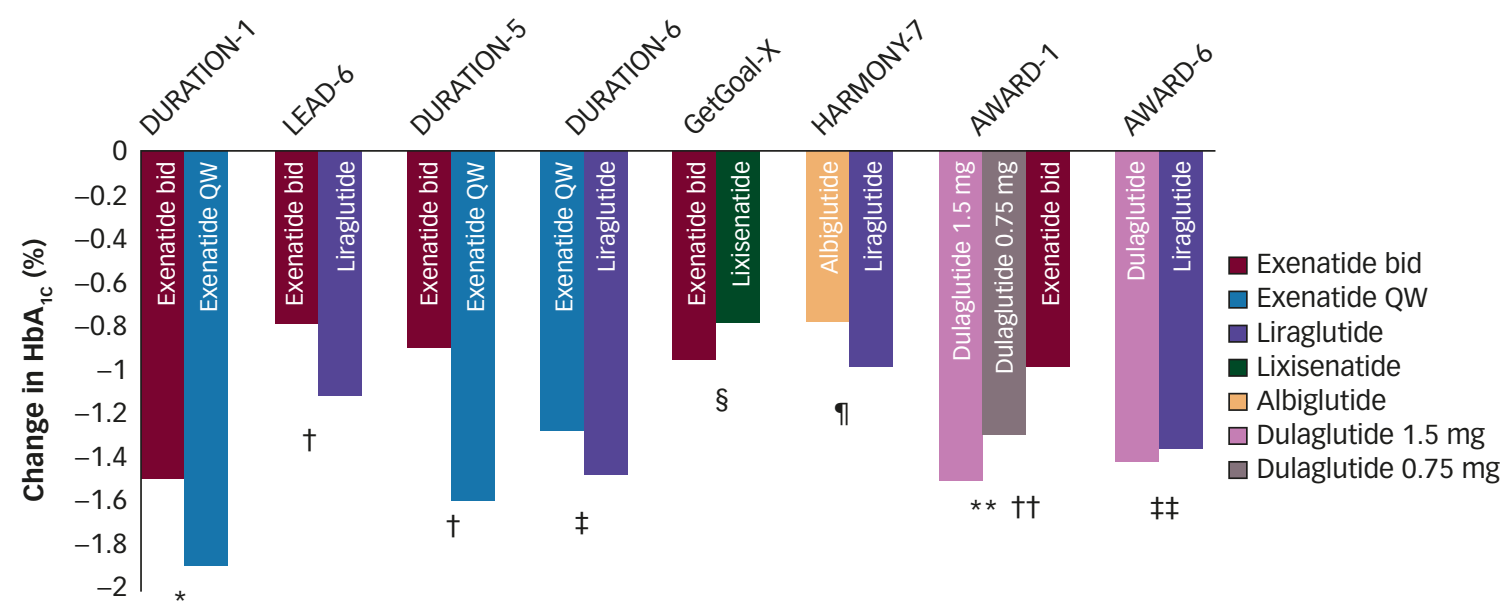

$p$ values are for statistical superiority unless otherwise noted as non-inferiority; ${ }^{*} p<0.0025 ;{ }^{+} p<0.0001 ; \neq p=0.02 ;{ }^{s} p=$ not significant, non-inferiority $p$ value not reported $(95 \%$ confidence interval $0.033-0.297$, meeting pre-defined non-inferiority margin); "non-inferiority $p$ value $=0.846$ (not meeting pre-defined non-inferiority margin); ${ }^{* *} p<0.001$ for both doses of dulaglutide versus exenatide bid; ${ }^{+t} p=$ not significant, non-inferiority $p$ value $<0.0001$ (meeting pre-defined non-inferiority margin). HbA ${ }_{1 c}=g / y c a t e d ~ h a e m o g l o b i n$. Reproduced with permission from Trujillo et al., 2015.17

\section{Figure 2: Body Weight Reductions with GLP-1 RA in Head-to-head Clinical Studies}

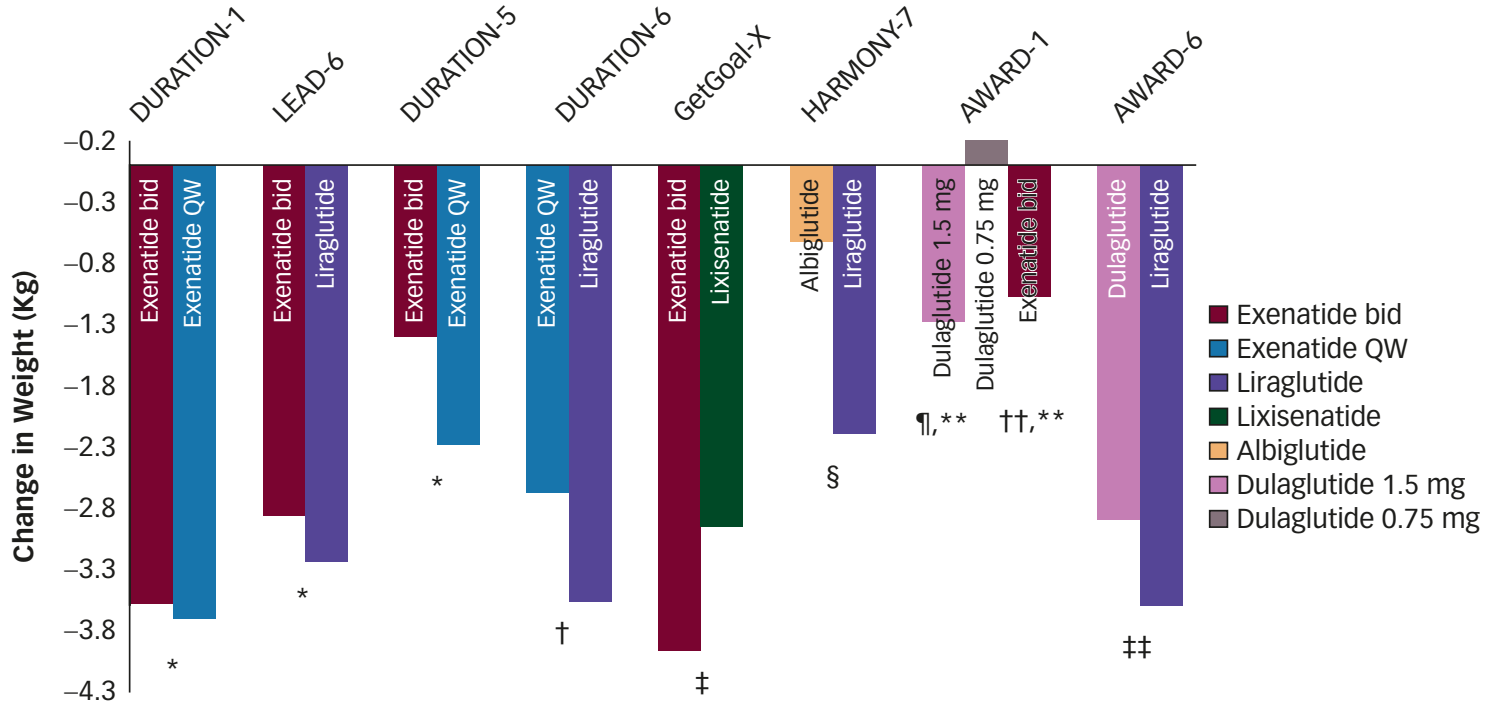

$p$ values are for statistical superiority (unless noted for non-inferiority); ${ }^{*} p=$ not significant; ${ }^{\dagger} p=0.0005 ;{ }^{\ddagger} p$ value not reported for weight difference of $1.02 \mathrm{~kg}$ ( $95 \%$ confidence interval

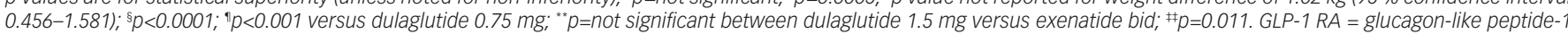
receptor agonists. Reproduced with permission from Trujillo et al., 2015. ${ }^{17}$

hypoglycaemic episodes and the adverse event profile was similar to other GLP-1 RAS.

\section{General Considerations about Long-acting GLP-1 Receptor Agonists}

The two novel long-acting GLP-1 RAs offer patients who have type 2 diabetes the advantage to lower the glycaemic parameters $\mathrm{HbA}_{10}$ and fasting and postprandial blood glucose while having a low risk of hypoglycaemia as well as the possibility of losing body weight. Generally, the gastrointestinal side effects (fullness and nausea) associated with GLP1 RAs are less severe and less sustained than those of the short-acting GLP-1 RAs. Head-to-head studies between albiglutide and dulaglutide have not been performed so far. The percentage of patients reaching their glycaemic targets during therapy with GLP-1 RAs has been greater than that achieved with most established therapies for type 2 diabetes mellitus. Figures 1 and 2 show the changes in head-to-head studies with GLP-1 RA for $\mathrm{HbA}_{1 \mathrm{c}}$ (see Figure 1) and body weight (see Figure 2). ${ }^{17}$
The long-acting GLP-1 RAS activate the GLP-1 receptor continuously, in contrast to the short-acting ones. The pharmacokinetic differences between these drugs lead to important differences in their pharmacodynamic profiles. The short-acting GLP-1 RAs mainly lower the post-prandial plasma glucose through inhibition of gastric emptying, whereas the long-acting compounds have a stronger effect on fasting glucose concentrations, which is mediated mainly through their insulinotropic and glucagonostatic actions. The adverse effect profiles of these compounds also differ. The individual properties of the various GLP-1 RAs might allow incretin-based treatment of type 2 diabetes mellitus to be tailored to each patient's needs. ${ }^{25}$ The once-weekly dosing interval of the novel GLP-1 RA may be an advantage for patients who present barriers to a once-daily injectable therapy and may give patients also more freedom to live a flexible life without daily therapeutic actions.

GLP-1 RA therapy may have beneficial effects beyond the glycaemic effects by direct action on the endocrine pancreas thanks to the widespread 
expression of GLP-1 receptors. These may include cardiovascular effects, effects on lipid metabolism, neurological disorders and beneficial effects on systolic blood pressure and body weight. These beneficial effects need to be counterweighed against possible side effects (e.g. gastrointestinal side effects, the increase of pulse rate observed with GLP-1 RA therapy). Data from the ongoing long-term safety studies are needed to judge whether the beneficial effects seen in preclinical and clinical trials will also improve long-term outcomes in the long run. Studies are also ongoing to elucidate the effects of GLP-1 RA in the treatment of type 1 diabetes in conjunction with insulin therapy, in which instance the effects of the GLP1 RA on gastric emptying and glucagon secretion may have beneficial effects on glycaemic control. ${ }^{25,26}$

\section{Liraglutide for the Treatment of Obesity}

A novel indication for the GLP-1 RA liraglutide is the treatment of obesity. Previous pivotal studies have already demonstrated a significant and sustained body weight reduction with liraglutide injected once daily at doses greater than the $1.2 \mathrm{mg}$ and $1.8 \mathrm{mg}$ used for diabetes. ${ }^{27} \mathrm{~A}$ large set of prospective clinical studies with more than 3,000 participants has subsequently investigated the effect of $3.0 \mathrm{mg}$ liraglutide daily on the reduction of body weight, cardiovascular effects and safety. In these studies, liraglutide demonstrated a significantly better body weight reduction with $3.0 \mathrm{mg}$ than with a $1.8 \mathrm{mg}$ dose and with placebo. Indeed, $65 \%$ of patients treated with the high dose of liraglutide lost more than $5 \%$ of their body weight. In participants who had type 2 diabetes, the glycaemic effects of both doses were comparable, whereas in study participants who did not have diabetes but who had prediabetes and obesity, the diabetes progression was retarded with use of the high dose of liraglutide. The reduction of blood pressure and the increase in pulse rate were comparable for both liraglutide doses. An improvement of cardiovascular surrogate risk markers was observed for $\mathrm{C}$-reactive protein (CRP), for the lipid parameters and brain natriuretic peptide (BNP). Non-biochemical risk parameters, symptoms and scores for sleep apnoea also improved.
All effects of liraglutide were reversible, as observed after a 12-week washout phase at the end of the study. ${ }^{28-30}$

The most common side effect of the $3.0 \mathrm{mg}$ dose of liraglutide was nausea (39\% versus $14 \%$ in the $1.8 \mathrm{mg}$ dose group) and other gastrointestinal side effects characteristic of the GLP-1 RA. Hypoglycaemia was more frequent in the patients who had type 2 diabetes and concomitant sulphonylurea therapy, despite the reduction of the sulphonylurea dose by $50 \%$ ( $15 \%$ versus $6 \%$ ). During the study, seven cases of pancreatitis were observed in the liraglutide group and one case was detected in the placebo group. The incidence of gallstone complications was also higher in the liraglutide group ( $2.3 \%$ versus $0.9 \%$ ). ${ }^{28-30}$

The US Food and Drug Administration (FDA) has approved the $3.0 \mathrm{mg}$ dose of liraglutide for the treatment of obesity. The specific indication for the use of liraglutide in obesity is as an adjunct to lifestyle for chronic weight management in individuals who have a body mass index (BMI) of >30 kg/ $\mathrm{m}^{2}$ (corresponding to the diagnostic criteria of obesity) or for subjects who are overweight and who have a BMl $>27 \mathrm{~kg} / \mathrm{m}^{2}$ or greater in the presence of at least one weight-related comorbidity, such as hypertension, diabetes or dyslipidaemia. Patients should be evaluated after 16 weeks and the drug discontinued if the patient has not lost at least $4 \%$ of baseline body weight.

With the approval for the indication obesity for liraglutide, uses for GLP-1 RAs have widened beyond diabetes. The results from the cardiovascular safety and outcome studies lately performed with GLP-1 RA will also answer important questions about the effects of GLP-1 RA and body weight-lowering drugs on cardiovascular risk and on safety. The study results so far show that a higher dose of a GLP-1 RA seems to be safe in terms of fears about increased pulse rate and increased risk of pancreatitis. That progression of diabetes is decreased in subjects with prediabetes on treatment with liraglutide is an interesting finding deserving of more attention in further studies of type 2 diabetes prevention.
1. Drucker DJ, Nauck MA, The incretin system: glucagon-like peptide-1 receptor agonists and dipeptidyl peptidase-4 peptide-1 receptor agonists and dipeptidyl peptidase-4 Gallwitz B, Glucagon-like peptide-1 analogues for Type 2 Gallwitz B, Glucagon-like peptide-1 analogues for Type 2
diabetes mellitus: current and emerging agents, Drugs, 2011;71:1675-88.

3. Muscogiuri $G$, Gastaldelli A, Albiglutide for the treatment of type 2 diabetes, Drugs Today (Barc), 2014;50:665-78.

4. Thompson AM, Trujillo JM, Dulaglutide: The newest GLP-1 receptor agonist for the management of type 2 diabetes, Ann Pharmacother, 2015;49:351-9.

5. Blonde L, Pencek R, MacConell L, Association among weight change, glycemic control, and markers of cardiovascular risk with exenatide once weekly: a pooled analysis of patients with type 2 diabetes, Cardiovasc Diabetol, 2015;14:12.

6. Kim D, MacConell L, Zhuang D, et al., Effects of once-weekly dosing of a long-acting release formulation of exenatide on glucose control and body weight in subjects with type 2 on glucose control and body weight in subj
diabetes, Diabetes Care, 2007;30:1487-93.

7. Young MA, Wald JA, Matthews JE, et al., Clinical pharmacology of albiglutide, a GLP-1 receptor agonist, Postgrad Med, 2014;126:84-97

8. National PBM Drug Monograph: Albiglutide (TANZEUM). Available at: www.pbm.va.gov/PBM/clinicalguidance/ drugmonographs/Albiglutide_monograph.pdf (accessed 5 March 2015).

9. Reusch J, Stewart MW, Perkins CM, et al., Efficacy and safety of once-weekly glucagon-like peptide 1 receptor agonist albiglutide (HARMONY 1 trial): 52-week primary endpoint results from a randomized, double-blind, placebo-controlled trial in patients with type 2 diabetes mellitus not controlled on pioglitazone, with or without metformin, Diabetes Obes Metab, 2014;16:1257-64.

10. Nauck M, Stewart M, Perkins C, et al., HARMONY 2 wk 52 results: Albiglutide monotherapy in drug naiive patients with type 2 diabetes mellitus; data presented at the Annual with type 2 diabetes mellitus; data presented at the Annual
Scientific Sessions of the American Diabetes Association (ADA) 2013, abstract number 2013-52-LB. Available at: www. abstractsonline.com/Plan/ViewAbstract.aspx?sKey $=0687 \mathrm{e} 7 \mathrm{c} 8$ c97d-442b-92ec-ae505e051854\&cKey=f5bf482f-533b-4cbd83d0-1bf4d18e46da\&mKey=\{89918D6D-3018-4EA9-9D4F711F98A7AE5D\}.

11. Ahrén B, Johnson SL, Stewart M, et al., HARMONY 3 Study
Group, HARMONY 3: 104-week randomized, double-blind, placebo- and active-controlled trial assessing the efficacy and safety of albiglutide compared with placebo, sitagliptin, and glimepiride in patients with type 2 diabetes taking metformin, Diabetes Care, 2014;37:2141-8.

12. Weissman PN, Carr MC, Ye J, et al., HARMONY 4: randomised clinical trial comparing once-weekly albiglutide and insulin glargine in patients with type 2 diabetes inadequately controlled with metformin with or without sulfonylurea Diabetologia, 2014;57:2475-84

13. Home PD, Shamanna P, Stewart M, et al., Efficacy and tolerability of albiglutide versus placebo or pioglitazone over 1-year in people with type 2 diabetes currently taking metformin and glimepiride: HARMONY 5, Diabetes Obes Metab, 2015;17:179-87.

14. Rosenstock J, Fonseca VA, Gross IL, et al., Harmony 6 Study Group, Advancing basal insulin replacement in type 2 diabetes inadequately controlled with insulin glargine plus diabetes inadequately controlled with insulin glargine plus GLP-1 receptor agonist, versus thrice-daily prandial insulin GLP-1 receptor agonist, versus thrice-daly
lispro, Diabetes Care, 2014;37:2317-25.

15. Pratley RE, Nauck MA, Barnett AH, et al., HARMONY 7 study group: Once-weekly albiglutide versus once-daily liraglutide in patients with type 2 diabetes inadequately controlled on oral drugs (HARMONY 7): a randomised, open-label, multicentre, non-inferiority phase 3 study, Lancet Diabetes Endocrinol, 2014;2:289-97.

16. Leiter LA, Carr MC, Stewart M, et al., Efficacy and safety of the once-weekly GLP-1 receptor agonist albiglutide versus sitagliptin in patients with type 2 diabetes and renal impairment: a randomized phase III study, Diabetes Care, 2014;37:2723-30.

17. Trujillo JM, Nuffer W, Ellis SL, GLP-1 receptor agonists: a review of head-to-head clinical studies, Ther Adv Endocrinol Metab 2015;6:19-28.

18. Wysham C, Blevins T, Arakaki R, et al., Efficacy and safety of dulaglutide added onto pioglitazone and metformin versus exenatide in type 2 diabetes in a randomized controlled tria (AWARD-1), Diabetes Care, 2014;37:2159-67.

19. Giorgino F, Benroubi M, Sun $\mathrm{H}-\mathrm{J}$, et al., Efficacy and safety of once weekly dulaglutide vs insulin glargine in combination with metformin and glimepiride in type 2 diabetes patients (AWARD-2), Diabetologia 2014;57(Suppl. 1):OP38.
20. Umpierrez $G$, Tofé Povedano S, Pérez Manghi F, et al., Efficacy and safety of dulaglutide monotherapy versus metformin in type 2 diabetes in a randomized controlled trial (AWARD-3), type 2 diabetes in a randomized con

21. Jendle J, Blonde L, Rosenstock J, et al., Better glycaemic control and less weight gain with once weekly dulaglutide vs bedtime insulin glargine, both combined with thrice daily lispro, in type 2 diabetes (AWARD-4), Diabetologia 2014;57(Suppl. 1):OP42.

22. Nauck M, Weinstock RS, Umpierrez GE, et al., Efficacy and safety of dulaglutide versus sitagliptin after 52 weeks in type 2 diabetes in a randomized controlled trial (AWARD-5), Diabetes Care, 2014;37:2149-58.

23. Nauck M, Weinstock RS, Umpierrez GE, et al., Efficacy and safety of dulaglutide versus sitagliptin after 52 weeks in type 2 diabetes in a randomized controlled trial (AWARD-5), Diabetes Care, 2015;38:538.

24. Dungan KM, Povedano ST, Forst T, et al., Once-weekly dulaglutide versus once-daily liraglutide in metformintreated patients with type 2 diabetes (AWARD-6): a randomised, open-label, phase 3 , non-inferiority trial, Lancet, 2014;384:1349-57

25. Meier JJ, GLP-1 receptor agonists for individualized treatment of type 2 diabetes mellitus, Nat Rev Endocrinol, 2012;8:728-42.

26. Unger J, Rationale use of GLP-1 receptor agonists in patients with type 1 diabetes, Curr Diab Rep, 2013;13:663-8.

27. Astrup A, Carraro R, Finer N, et al., NN8022-1807 Investigators, Safety, tolerability and sustained weight loss over 2 years with the once-daily human GLP-1 analog, liraglutide, Int J Obes (Lond), 2012:36:843-54.

28. Le Roux C, Lau DCW, Astrup A, et al., Safety and tolerability of liraglutide $3.0 \mathrm{mg}$ in overweight and obese adults: the SCALE obesity and prediabetes randomised trial, Diabetologia SCALE obesity and prediab

29. Pi-Sunyer X, Fujioka K, Le Roux C, et al., Liraglutide $3.0 \mathrm{mg}$ reduces the prevalence of prediabetes and delays onset of type 2 diabetes in overweight/obese adults: the SCALEb obesity and prediabetes trial, Diabetologia, 2014;57(9 Supp 1):OP-73.

30. Abreu C, Gómez-Peralta F, Castro J, et al., Influence of liraglutide treatment in obstructive sleep apnoea in obese type 2 diabetes patients, Diabetologia, 2014;57(9 Suppl. 1):P-910. 